\title{
Mental health support in Wales
}

\section{Christie Owen and Dr Caroline Seddon}

BDA Wales

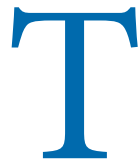
ired? Stressed? Anxious? Trouble sleeping? Using alcohol to numb the symptoms? Feeling burned out? Our survey of dentists showed that almost half of those who responded say that stress in their job is exceeding their ability to cope. This is an incredibly worrying picture.

Dentistry is a challenging profession that can often lead to episodes of poor mental health, especially for dentists working largely in the NHS, as the BDA has repeatedly demonstrated. $^{2}$

While we work hard on your behalf to tackle the many causes of stress, such as the 2006 GDS contract and the General Dental Council's handling of complaints against dentists, there is inevitably a continuing need for mental health support services. We want to know what you think of the provision in Wales today.

BDA UK research has shown dentists want to see:

$\rightarrow$ More awareness within the profession around how to identify people at risk

$\rightarrow$ The stigma removed from mental ill-health

$\rightarrow$ To be able to talk to others; to overcome isolation; to share experiences and solutions to problems. ${ }^{3}$

But what services are available? England now has the NHS Practitioner Health Service for doctors and dentists, however there is no equivalent service in Wales for dentists.

We recently undertook research into what is available locally in Wales for dentists' mental health support. There is a government-funded scheme for GPs and last year we asked Welsh Government whether they will extend this service to be made available for GDPs as well. We understand this was being considered.

In 2019 the BDA launched Health Assured, a telephone advice and counselling service for all BDA members, which can include face-toface sessions. In parallel, the Benevolent Fund is also offering this service.

\begin{tabular}{|c|c|c|c|}
\hline Organisation & Sent & Response & Support \\
\hline Powys HB & 09/12/2019 & 10/12/2019 & $\begin{array}{l}\text { Nothing at the moment, they would need more funding and } \\
\text { asked if there is government funding available }\end{array}$ \\
\hline Cardiff \& Vale HB & 09/12/2019 & $20 / 01 / 2020$ & No Support \\
\hline Betsi HB & 09/12/2019 & $20 / 01 / 2020$ & $\begin{array}{l}\text { No Support if not direct employees, they expect own unions } \\
\text { to deal with professional side or expect them to see a GP }\end{array}$ \\
\hline SBUHB & $09 / 12 / 2019$ & $15 / 12 / 2019$ & $\begin{array}{l}\text { Liaise with the LDC who provide a contact and independent } \\
\text { professional support }\end{array}$ \\
\hline Aneurin Bevan HB & $09 / 12 / 2019$ & $20 / 01 / 2020$ & No Support \\
\hline Cwm Taf HB & 09/12/2019 & $10 / 12 / 2019$ & $\begin{array}{l}\text { Counselling service available to GDPs. Was advertised by } \\
\text { an Email when it was set up. They do not record how many } \\
\text { dentists have accessed it }\end{array}$ \\
\hline Hywel Dda HB & $09 / 12 / 2019$ & $09 / 12 / 2019$ & No Support \\
\hline Bro Taf LDC & $09 / 12 / 2019$ & $09 / 12 / 2019$ & $\begin{array}{l}\text { There are } 3 \text { dentists within the LDC whom dentists can call } \\
\text { confidentially }\end{array}$ \\
\hline Gwent LDC & $09 / 12 / 2019$ & $10 / 12 / 2019$ & No Support \\
\hline Dyfed Powys LDC & $09 / 12 / 2019$ & $22 / 01 / 2020$ & No Support \\
\hline North Wales LDC & $09 / 12 / 2019$ & $17 / 01 / 2020$ & No Support \\
\hline Morgannwg LDC & $09 / 12 / 2019$ & $09 / 12 / 2019$ & $\begin{array}{l}\text { Occasionally they might have a request from a DPA to advise } \\
\text { someone with problems, it is as confidential as it can be }\end{array}$ \\
\hline
\end{tabular}

It is clear from our research in Table 1 that although Health Boards provide mental health support services to salaried dentists via their occupational health schemes, there is no such provision for GDPs in six of the seven Health Boards. Cwm Taf is the only Health Board to offer this. The other Health Boards' occupational health departments said in response to our enquiries that mental health support was not covered for GDPs. When we queried this picture with a Government official they said that there is Government funding for Occupational Health services that should cover mental health support. Clearly, the six Health Boards didn't get the memo.

It is no surprise that, due to a lack of provision, various not-for-profit organisations have tried to plug the gap, including Confidental, and Dentists Health Support Trust. Mental Dental is a Facebook Group for self-support among dentists, which currently has 5,585 members, so there is clearly a need for these volunteer-led support services.

Last month The BDA held a mental health round-table event, led by BDA President Roz
McMullan, to discuss these issues and more. For anyone who has met Roz, you will know of her passion about tackling this issue across the UK on behalf of all dentists. There is a clear focus on what more needs to be done across the UK to alleviate stress on our workforce.

We are keen to hear from you about what you think of the current support services available for dentists in Wales and what else you would like to see provided. Would you value an arm's length service tailored for all dentists? Please get in touch, because together, we are stronger.

\section{References}

1. Toon M, Collin V, Whitehead P and Reynolds L. An analysis of stress and burnout in UK general dental practitioners: subdimensions and causes. Br Dent J 2019; 226: 125-130.

2. British Dental Association. Tackling stress in dentistry. Available online at: https://bda.org/stress (Accessed February 2020).

3. Larbie J, Kemp M and Whitehead P. The mental health and well-being of UK Dentists: A Qualitative Study. Available online at: https://bda.org/about-thebda/campaigns/Documents/The\%20Mental\%20 Health\%20and\%20Well-being \%20of\%20UK\%20 Dentists.pdf (Accessed February 2020).

https://doi.org/10.1038/s41404-020-0330-y 